Article

\title{
Entrepreneurial Orientation: Its Relationship with the Entrepreneur's Subjective Success in SMEs
}

\author{
Guadalupe Manzano-García and Juan-Carlos Ayala-Calvo *(i) \\ Chair of family businesses, Universidad de la Rioja, 26004 Logroño, La Rioja, Spain; \\ guadalupe.manzano@unirioja.es \\ * Correspondence: juan-carlos.ayala@unirioja.es
}

Received: 12 May 2020; Accepted: 2 June 2020; Published: 3 June 2020

\begin{abstract}
Previous research has underlined, normally from a firm-level perspective, the importance of entrepreneurial orientation in explaining objective entrepreneurial success. Nevertheless, its impact on the perception of entrepreneurs with respect to what entrepreneurial success means to them remains underexplored. Based on a sample of manager-owners of small companies, and contemplating entrepreneurial orientation as an individual concept, we used a time-lagged design with two data-collection points to explain the effect of innovative orientation (IO), risk-taking orientation (RTO) and proactive orientation (PO) on the subjective success of entrepreneurs. Our results show that only one dimension of entrepreneurial orientation, proactive orientation, is associated with entrepreneurs' satisfaction with their activity, life, organization and the growth of the company.
\end{abstract}

Keywords: entrepreneurs; entrepreneurial orientation; subjective success

\section{Introduction}

An entrepreneur is a person who has started or owns a business [1]; they are an individual with a special gift for recognising opportunities and an ability to mobilise external, human and financial resources to take advantage of those opportunities [2]. The ability to interpret situations and events differently and to recognise opportunities, as well as an entrepreneurial orientation, are some of the characteristics that define a successful entrepreneur.

The entrepreneurial orientation has often been considered a firm-level characteristic [3] However, its measurement is usually based on self-reports by individuals, mostly owners [4,5]. This has led some authors to advocate the use of the entrepreneurial orientation as an individual-level concept, especially in the context of the firm's first owner-managers of small businesses [6]. Their argument is based on the fact that the values and behaviour of first owner-managers of small organizations are strongly integrated into the strategic orientation of the company. As leaders of the organisation, the first owner-managers of small enterprises exert a critical influence on their companies' activities and processes [6]. We consider entrepreneurial orientation as an individual level concept of the firm's owner-manager. Thus, the entrepreneurial orientation refers the firm' entrepreneurial strategy-making processes, and it characterizes the extent to which the owner-managers are inclined to be innovative, risk-taking and proactive [6]. Although there are more and more authors who defend the fact that entrepreneurial orientation can be translated to individual level [5,7], it remains unclear how entrepreneurial orientation at individual level relate to entrepreneurial success [3].

Prior studies argued that firms with a strong entrepreneurial orientation will be more successful than companies with a lower entrepreneurial orientation. This argument is based on the idea that entrepreneurial orientation is a potential source of competitive advantage [5]. Most of the these works have used financial indicators such as growth of the business, profitability or share price to measure the firm's success $[1,8]$. Nevertheless, in the last 10 years, this measurement of success has been 
questioned as it does not take into consideration the entrepreneur's perception of what the firm's success means to them [9-12]. In the opinion of Lian and Yen [13], compared to the studies that use financial indicators or hard measurements, in the literature, there is an evident lack of research that uses subjective measurements or soft measurements. According to Cooper and Artz [14], satisfaction is clearly a key measure of success for the entrepreneur. For Lian and Yen [13], the best measure of a firm's success is the entrepreneur's degree of satisfaction. The discrepancy theory [15] approach we used in this investigation states that individuals' satisfaction is determined by whether there is a gap between actual performance and the individual's expectations [14].

We used subjective measurements of success in our paper. Specifically, we used four measurements of the entrepreneur's satisfaction: satisfaction with the entrepreneurial activity (SEA), satisfaction with life (SL), satisfaction with the organization (SO) and satisfaction with the growth of the firm (SG). Each of these four measures describes the satisfaction that individuals may or may not experience within a very specific domain.

In prior research on the relation between entrepreneurial orientation (from an individual-level perspective) and the entrepreneur's success, some authors have used global entrepreneurial orientation measures, contemplating it as a single construct comprised of the sum of various dimensions or factors [16]. Others, however, have argued that each of the dimensions of the entrepreneurial orientation could have a different influence in the explanation of entrepreneurs' satisfaction [13,17]. According to Casillas et al. [18], the literature on entrepreneurial orientation should conduct a more in-depth study on how and to what degree each of the different dimensions of entrepreneurial orientation influence, separately, the entrepreneur's success.

In small enterprises, consideration of entrepreneurial orientation includes the need to take into account the individual behaviour of first owner-manager. This is required to provide an idea of the existing relations between the individual's behaviour and the satisfaction that they experience. It could also allow us to understand how each of the dimensions of entrepreneurial orientation may contribute to the explanation of each of the dimensions of entrepreneurial satisfaction. Thus, the main objective of this study was to examine how the entrepreneurial orientation influences the levels of satisfaction for first owner-managers. Specifically, we are interested in knowing the extent to which the inclination of the first owner-manager to be innovative, risk-taking or proactive helps explain their satisfaction with the entrepreneurial activity (SEA), life (SL), the organisation (SO) and the growth of the firm (SG). Studying these relationships can be interesting for both entrepreneurs and policy-makers, because the future of the company can depend on these. This is due to the fact that the most satisfied entrepreneurs work more efficiently and maintain closer relations with different stakeholders, which would make them more likely to continue the business instead of closing it [14].

Our study contributes to a better understanding of the relationship between entrepreneurial orientation and the entrepreneur's satisfaction, on which there are very few studies published [19], in several directions. On the one hand, we expand our limited understanding on entrepreneurial satisfaction. Instead of using a single measure for the overall satisfaction of first owner-managers, we used four different types of satisfaction: satisfaction with the entrepreneurial activity, life, the organization and the growth of the firm. This differentiation is relevant since there are different dimensions of satisfaction [13,20]. Carree and Verheul [21] suggested that the sum of the different dimensions of satisfaction might not be equivalent to a global measure of satisfaction. On the other hand, this study expands our limited understanding of the aspects of the individual's entrepreneurial orientation that influence their satisfaction. In this regard, this study expands on the research on the relation between entrepreneurial orientation (from an individual-level perspective) and entrepreneur satisfaction (subjective success) by testing different models that jointly consider the dimensions of both constructs. In each of these models, the influence of other variables (individual-specific and venture-specific) is also tested. In previous studies, these variables have been linked to job satisfaction or life satisfaction [13]. However, we do not know of any previous work that has investigated its relationship of the first owner-manager's satisfaction with their company's organisation or growth. 
Therefore, our work also contributes to increasing the empirical evidence on whether gender, age, education, family situation, activity sector or time devoted to the business have a similar and significant influence on the explanation of each of the dimensions of satisfaction studied here. In addition, this work provides an insight into discrepancy theory by considering its application in a sample of first owner-managers and not in a sample of employees, which is the usual. Lastly, we used a time-lagged design, which allowed us to overcome some of the limitations of the cross-sectional studies used by most of the prior studies.

The background literature and hypotheses, research method, data analysis, results, discussions, robustness analysis and conclusions and further developments are presented in sequence in the following sections of this paper.

\section{Background Literature and Hypotheses}

\subsection{Entrepreneur's Subjective Success}

In recent years, several authors have defended that a firm's success must be measured using subjective measures, that take into account the entrepreneur's perception of what the firm's success means for him [9]. Entrepreneurial success is a complex phenomenon that includes financial and non-financial aspects $[22,23]$. The diversity of aspects that entrepreneurs value and try to achieve are not only of an economic type [11], related to increasing the value of the company and/or seeking to decrease financial risks to prevent and avoid bankruptcy [24] For Lian and Yen [13], the best measure of a firm's success is the entrepreneur's degree of satisfaction. According to Carree and Verheul [21], satisfaction can be seen as the key factor for measuring subjective entrepreneurial success.

The self-determination theory $[19,25]$ states that individuals' subjective wellbeing and satisfaction results from the fulfilment of three basic psychological needs: autonomy, competence and relatedness. On the other hand, the discrepancy theory [15] suggests that a person's satisfaction comes from what they feel is important rather than the fulfilment or non-fulfilment of their needs. The discrepancy theory proposes that satisfaction experienced by the entrepreneur is related to a cognitive comparison process. That is, satisfaction is determined by some type of perceived gap between what the entrepreneur has now and what they wanted to have [14]. In previous research, the most studied perceived gap in relation to entrepreneurs is that between expectations (the expected situation) and the current situation (what actually happens) $[14,21,23,26]$. This is the criteria that we adopted in our paper.

According to Powell and Eddleston [27], the entrepreneur's global satisfaction is a multidimensional construct that has two essential components: job satisfaction and life satisfaction. For Dej [28], to these two components, which are related to the personal development and personal goals of the entrepreneur, we should add other components, also subjective, related to satisfaction with the income and finances of the firm. According to Dijkhuizen et al. [20], indicators that measure satisfaction with the organisation and with its more economic/financial aspects should be included. These four components were taken in this study. Our work used satisfaction with the entrepreneurial activity (job satisfaction), with life, with the organisation and with the growth of the firm to measure subjective entrepreneurial success [22]. Satisfaction was defined in our paper as the evaluation by the entrepreneur, according to his own criteria, of his entrepreneurial activity, his life, his organisation or its growth $[13,29]$.

\subsection{Innovative Orientation and Entrepreneurial Satisfaction}

An innovative orientation implies the individual's willingness to create and develop new ideas, experimenting and trying to develop new products, services or new technologies [30,31]. Innovative orientation not only implies creating new ideas, it also implies the implementation of new ideas [32].

Most previous studies have linked innovation with pecuniary outcomes [33,34]. However, more and more authors are defending the link between the owner-manager's entrepreneurial orientation and the increase in non-pecuniary benefits in the form of satisfaction $[19,21]$. Some authors have 
shown, as evidenced by Huhtala and Diehl [35] in their literature review, that there is a negative relationship between innovation and job satisfaction. This relationship is linked to the stress generated by innovation processes. Being innovative often means following a complex, non-linear route, with uncertain results. In addition, it means having to struggle with those who are against the idea, convincing those involved in the innovation process to not hinder the change, or facing conflicts with stakeholders [36]. However, some authors suggest that the tensions associated with the innovation process could be significantly reduced if the process is properly organised [19]. In this case the positive emotions experienced by the owner-managers in initiating "creative construction" processes and/or implementing new ideas in their businesses tend to be much greater than the negative emotions (related to stress created by innovative processes). As a result, these authors argue that there is a positive relationship between innovation and job satisfaction $[37,38]$.

Given that innovation involves the implementation of ideas and processes that are useful and beneficial to the organisation and its management [31], the entrepreneur will experience personal satisfaction in creating an organisation that operates efficiently, that is worried about workers' satisfaction and health. In addition, they will experience personal satisfaction when providing their customers with innovative products and services [39], which will probably be the basis of the company's growth. In the words of Wickstrøm et al. [19], this satisfaction extends from the domain of work to social relationships (family, friends, society, etc.), which will probably lead to an improvement in the perception of their life satisfaction [19,40-42]. Thus, although these relationships have not been tested in samples of entrepreneurs, based on the above arguments, we hypothesise as follows:

H1a: The entrepreneur's innovative orientation positively influences satisfaction with their entrepreneurial activity.

H1b: The entrepreneur's innovative orientation positively influences their satisfaction with life.

H1c: The entrepreneur's innovative orientation positively influences their satisfaction with the organisation.

H1d: The entrepreneur's innovative orientation positively influences their satisfaction with their company's growth.

\subsection{Risk-Taking Orientation and Entrepreneurial Satisfaction}

Risk-taking orientation refers to the tendency of the entrepreneur to make decisions that entail compromising the firm's resources by taking calculated risks [43]. Although taking calculated risks means reducing the chances of error, the entrepreneur cannot avoid having to constantly take on risks and challenges, in view of the prevailing uncertainty in the environment in which they develop their activity. Continually taking risks will cause a certain degree of tension and stress for the entrepreneur [8]. However, a positive orientation toward risk taking can help them take on these inevitable challenges and risks [5] and therefore decrease stress and increase their satisfaction with their own decision making.

According to Knight [44], the risk-taking orientation leads entrepreneurs to make correct decisions because they are able to assess the probability of success associated with their decisions, even under conditions of uncertainty. Tetrick et al. [45] showed that owner-managers experienced less emotional exhaustion than managers who were not owners. Andersson [46] found that owner-managers were less likely to perceive their work as mentally stressful. For some authors, risk-taking is a key factor in entrepreneurial orientation and could influence both entrepreneurs' decisions as well as their perception of success [47,48]. Carree and Verheul [21] and Sriprasert [17] have shown that risk-taking orientation could have a direct effect on both the entrepreneur's job satisfaction and life satisfaction. Lian and Yen [13] found a positive relationship between risk-taking orientation and the satisfaction of entrepreneurs online.

Previous research has shown that there is a positive relationship between owner-managers' risk-taking orientation and the growth in a company's sales and/or assets [49,50]. However, the relationship between owner-managers' risk-taking orientation and satisfaction with the growth of 
their company has never been studied. Owner-managers tend to focus on long-term objectives and are not very concerned by the rapid and balanced growth of their companies. Growing usually means compromising the company's resources, even those of the owner-manager and their family [51]. For this reason, the owner-manager takes calculated risks aimed at achieving sustainable growth, based on financial stability and the conservation of the company's wealth [52,53]. Therefore, the risk-taking orientation could influence the owner-manager's decisions on the growth of their company and therefore their satisfaction with it $[47,48]$. As well as conditioning the size of the company, the owner-manager's greater or lesser disposition to taking calculated risks could also influence the definition of the organisation chart, the formulation of strategies, policies and organisational practices or the work environment. These variables could explain both the type of organisation as well as the owner-manager's satisfaction with it $[47,48,54]$. Thus, although there are hardly any studies that looked at the relationship between the entrepreneur's risk-taking orientation and satisfaction with their entrepreneurial activity; and/or life satisfaction; and although we do not know of any studies that look at the relationship between the entrepreneur's risk-taking orientation and their satisfaction with the organisation and/or their company's growth, we make the following hypotheses based on the above arguments.

H2a: The entrepreneur's risk-taking orientation positively influences satisfaction with their entrepreneurial activity.

H2b: The entrepreneur's risk-taking orientation positively influences their satisfaction with life.

H2c: The entrepreneur's risk-taking orientation positively influences their satisfaction with the organisation.

H2d: The entrepreneur's risk-taking orientation positively influences their satisfaction with their company's growth.

\subsection{Proactive Orientation and Entrepreneurial Satisfaction}

Proactive orientation is the individual' ability to anticipate changes or market needs; the ability to act before changes take place, instead of waiting for them to take place and then reacting. Proactive orientation is a feature of those entrepreneurs that seek to become leaders in their market, exploring opportunities and anticipating future demand, developing new products or services ahead of their competitors [55]. Proactive orientation leads entrepreneurs to continuously try to improve, to search for different alternatives to achieve their objectives, to evaluate opportunities and threats in the environment and predict the possible results of their decisions [56].

The relationship between proactive orientation and satisfaction has been studied in samples of workers: Siebert et al. [57] showed that proactive orientation was positively related to life satisfaction. Erdogan and Bauer [58] showed that proactive orientation was positively related to job satisfaction. Although it is clear that there are differences between the entrepreneur and self-employed people (entrepreneurs work in a company that they have created, put in place strategies that they have designed themselves, the company's profits are their property), the former's greater commitment to the organisation suggests that these results could be maintained for samples of entrepreneurs [17]. On the other hand, previous research has suggested that proactive orientation could positively influences the owner-manager's satisfaction with their decisions and with the different domains affected by such decisions (work, life, organisation, company's growth) [57]. This relationship is based on the idea that a choice based on analytical decision making patterns is more likely to be good and, therefore, increases the chances of achieving the desired result [59]. In turn, it is expected that the achievement of objectives increases the entrepreneur's satisfaction, provided that those objectives are the ones pursued [60]. Thus, although hardly any studies have investigated the relationship between proactive orientation and entrepreneur's satisfaction [61], based on the above arguments, we hypothesize as follows:

H3a: The entrepreneur's proactive orientation positively influences satisfaction with their entrepreneurial activity.

H3b: The entrepreneur's proactive orientation positively influences their satisfaction with life.

H3c: The entrepreneur's proactive orientation positively influences their satisfaction with the organisation. 
H3d: The entrepreneur's proactive orientation positively influences their satisfaction with their company's growth.

\section{Materials and Methods}

\subsection{Sample and Procedure}

The participants were entrepreneurs, first owners-managers of a Spanish private firm, which was active in 2017, was over 4 years-old and employed more than 10 and less than 50 staff members. It is possible that the importance of the first owner-manager in the company's entrepreneurial orientation depends on its size. As the company grows, the influence of the first owner-manager becomes less critical and the organisational structure and middle managers gain more importance in the determination of the company's entrepreneurial orientation [5]. For this reason, our work focused on businesses with fewer than 50 employees, where the influence of the first owner-manager is critical. While business routines experience some degree of stabilisation after 4 years of experience managing a company, uncertainties about the changes that are needed in the organisation, the company's growth and life-family conflicts do not go away. However, 4 years is a long enough time for the entrepreneurs, based on the events of that period, to assess their satisfaction with their entrepreneurial activity, life, organisation and company growth in accordance with their own criteria. Using an online questionnaire, the entrepreneurs (first owner managers) were surveyed in 2017 and again in 2018. Past research has shown that online questionnaires are as valid and reliable as traditional paper-and pencil questionnaires $[62,63]$.

The sample needed for this study, calculated with the help of $G^{*}$ Power v.3.1.9.2 software [64], taking into consideration a size effect $\left(\mathrm{f}^{2}\right)$ of 0.15 [65] and an error level $(\alpha)$ of 0.05 , was 131 observations. The entrepreneurs (655) were selected randomly from the database managed by the Family Business Institute [66]. This database contains 113,546 small family firms of which 53.6\% (60,860 firms) are in the first generation. It is estimated that $90 \%$ of these companies are managed by the first owner. The 655 entrepreneurs represent 5 times the number of minimum necessary observations. It was decided that 655 first owner managers would be chosen as we were aware of entrepreneurs' low response rate in research of this kind. All participants were confidential and volunteers. In the fourth quarter of 2017 (T1), we gathered data on entrepreneurial orientation. In the fourth quarter of 2018 (T2), we gathered data on satisfaction. In order to maximise the response rate, both in $\mathrm{T} 1$ and in $\mathrm{T} 2$ we sent two reminder emails: the first a week after the email containing the survey and the second one two weeks later. Although one year lag was chosen basically for practical reasons, to avoid significant experimental mortality, it was deemed appropriate based on previous studies indicating that entrepreneurial orientation tends to remain stable over time [67]. However, major changes, for example changes in the company's ownership, growth strategy, family relationships or other major organisational events (e.g., restructuring) could influence entrepreneurial orientation. For this reason, using a short questionnaire of 5 items (e.g., "Have you changed your \% of the company's ownership?"), we checked if the participants' working conditions had undergone any major changes in 2018 compared to 2017. Everyone surveyed answered each and every item negatively.

Of the 655 online questionnaires sent in 2017, 206 participants returned usable questionnaires (response rate $=31.45 \%$ ). In October 2018 (T2), we contacted these 206 individuals again and asked them to fill in a computer-administered questionnaire to measure satisfaction. 200 questionnaires were returned $(97 \%)$ but 6 had to be discarded as they were incomplete. The final sample comprised 194 individuals, indicating a reliability sample power of $95.68 \%$.

Our sample size is very similar to that used in previous works that have linked the entrepreneurial orientation with the entrepreneur's success: Lumpkin and Dess [68], 124 responders; Lechner and Gudmundsson [69], 117 responders; Shan et al. [34], 153 responders; Martens et al. [70], 100 responders. The comparison of the features of the final sample (194 individuals) with the group of individuals that were lost (12 individuals) showed that there were no significant differences between them. 
The final sample was comprised of entrepreneurs whose firms worked in different sectors of the economy: agriculture $(7.7 \%)$, industry $(8.8 \%)$, construction $(8.2 \%)$ and services $(75.3 \%)$. The proportion of firms in each sector is very similar to the distribution of firms in the sectors of the Spanish economy [71]. The average number of employees of each firm was 23.90 ( $\mathrm{SD}=13.24$; range $10-50$ employees). $73.2 \%$ of the participants in the study are men; $54.1 \%$ hold degrees, $38.7 \%$ completed secondary studies and $7.2 \%$ primary studies; $90.2 \%$ of the individuals in the sample live with their significant other, compared to $9.8 \%$ who do not live with their significant other. Respondents, on average, were 49.39 years old ( $S D=9.30$, range 25 to 73 years), had 17.70 years of experience in their current workplace $(S D=10.14$; range 4 to 45 years), had 1.31 children (SD $=0.96$; range 0 to 3 children) and worked $49.47 \mathrm{~h} /$ week ( $\mathrm{SD}=9.33$; range 23 to $72 \mathrm{~h} /$ week).

\subsection{Measures}

This study included three dimensions of entrepreneurial orientation (innovative orientation, risk-taking orientation and proactive orientation) and four of entrepreneurial satisfaction (satisfaction with the entrepreneurial activity, satisfaction with life, satisfaction with the organization and satisfaction with the growth of the firm). Entrepreneurial orientation was measured using an adaptation of the items proposed by Shan et al. [34]: three items to measure innovative orientation (e.g., "In my company, I constantly look for ways to do things differently."), three for risk-taking orientation (e.g., "The capacity to assume risks is one of my personality traits."); and three for proactive orientation (e.g., "In my company, I always try to take the initiative in any situation."). Respondents, using a Likert-type scale ranging from 1 "totally disagree" to 5 "totally agree" had to choose to what extent the item defined the characteristics of their entrepreneurial orientation. Cronbach's alpha for each of the scales was: 0.75 for risk-taking orientation, 0.72 for innovative orientation and 0.75 for proactive orientation.

We used measures of a single item to evaluate satisfaction with the entrepreneurial activity ("Compared to my expectations, right now, I am satisfied with my entrepreneurial activity"), life ("Compared to my expectations, right now, I am satisfied with my life"), the organization ("Compared to my expectations, right now, I am satisfied with my organisation") and the growth of the firm ("Compared to my expectations, right now, I am satisfied with my firm's growth"). Answer categories range from (1) "totally disagree" to (5) "totally agree". Boes et al. [72], Carree and Verheul [21] or Kibler et al. [73] defended that it is better to measure satisfaction with a single item than to use a combination of items. The dimensions of satisfaction that were used try to capture the degree to which entrepreneurs believe that the current situation matches what they initially expected. The items used in the study were adapted based on those proposed by Carree and Verheul [21] and Lian and Yen [13].

Excluding the sociodemographic variables, our questionnaire consists of 13 items. It is a "pragmatic" questionnaire for "real" entrepreneurs, which tries to avoid any rejection of participating respondents [74]. A bilingual entrepreneur (fluent in Spanish and English) translated the items of the questionnaire into Spanish, after which two other bilingual Spanish entrepreneurs translated the Spanish version back into English. After this, five bilingual Spanish entrepreneurs filled out the questionnaires. The entrepreneurs were then asked to compare the Spanish translation with the English translation and they concluded that the reverse-translation was sufficiently similar to the original items.

\subsection{Control Variables}

Based on the previous literature on entrepreneur's satisfaction $[13,20,21]$, the control variables considered were: gender $(\mathrm{G})(1=$ man; 2 = woman), education $(\mathrm{E})(1=$ primary studies; 2 = secondary studies; 3 = degree), age of the entrepreneur (A), life-partner(LP) (with (1) or without (2) a significant other), number of children $(\mathrm{CH})$, years of experience in their current workplace (ECJ), activity sector (AS) (1 = Agriculture; 2 = Industry; 3 = Construction; 4 = Services) and hours worked weekly (HWW). 


\subsection{Data Analysis}

In order to determine the role that innovative, risk-taking and proactive orientation play in explaining the entrepreneur's satisfaction with their entrepreneurial activity, life, organisation and the growth of their company, we used four models of hierarchical linear regression. In all models, the independent variables were innovative orientation, risk-taking orientation and proactive orientation. In model 1, the dependent variable was satisfaction with the entrepreneurial activity; in model 2 was satisfaction with life; in model 3 was satisfaction with the organisation; and in model 4 was satisfaction with the growth of the firm. In each of the models, we first added the control variables and then the independent variables. The validity of each model was evaluated according to $R^{2}$, adjusted $R^{2}$ and $F$ test of statistical significance.

\section{Results and Discussion}

Table 1 shows the average value, the standard deviation and the intercorrelations between the variables included in the study. The results confirmed the discriminant validity as all of the correlations are under 0.61 , below the 0.85 threshold established by several authors as the critical point [75]. The gender-age, education-age and experience-education correlations were negative and statistically significant. These results support those shown by the GEM Spain 2019 report [76] and indicate that the older the entrepreneurs, the lower the percentage of women and the lower the education level attained. On the other hand, the higher an entrepreneur's education level, the less professional experience they have in their current job. The results show that the correlations between the four measures used to assess entrepreneur satisfaction are positive and statistically significant. The same occurs with the correlations between the factors of entrepreneurial orientation. Furthermore, the results showed that the correlations between innovative orientation and each of the dimensions of entrepreneur satisfaction are positive and statistically significant. The same occurs with the correlations between proactive orientation and the 4 dimensions of entrepreneur satisfaction. However, the risk-taking orientation only showed a positive and statistically significant correlation with satisfaction with growth.

The Beta coefficients of the regression analysis for each of the hierarchical regression models, as well as their corresponding standard errors, are displayed in Table 2. Much as in the rest of analysed models, the Durbin-Watson statistics showed that the serial correlation of residuals takes values that are within the acceptance range (1.5 and 2.5). This means that there is no auto-correlation problem in the data. In all cases, the variance inflation factor (VIF) values remained below the recommended maximum value, which is around 5 . This means that there is no multi-collinearity problem in the regression models used for this study.

The $R^{2}$ value of each of the models showed values above 0.16 , and the adjusted $R^{2}$ was above 0.10 . Considering that we are working with variables that attempt to measure human behaviour, the resultant $R^{2}$ values are considered acceptable for this research area [77]. The values of the coefficient of determination $\left(\mathrm{R}^{2}\right)$ of our models are similar to those shown in previous studies that have measured entrepreneurs' subjective success $[13,20,21]$. We should also consider that $R^{2}$ provides an estimate of the strength of the relationship between the predictor variables and the dependent variable, but does not provide a formal hypothesis test for this relationship. The test that determines whether this relationship is statistically significant is the $\mathrm{F}$ test of statistical significance. In the four models analysed, the F value was significant $(p<0.01$ for model 1 and $p<0.001$ for models 2,3 and 4 ). 
Table 1. Descriptive statistics and correlations.

\begin{tabular}{|c|c|c|c|c|c|c|c|c|c|c|c|c|c|c|c|c|c|}
\hline & Mean & $S D$ & 1 & 2 & 3 & 4 & 5 & 6 & 7 & 8 & 9 & 10 & 11 & 12 & 13 & 14 & 15 \\
\hline 1. $G$ & 1,27 & 0,44 & 1.00 & & & & & & & & & & & & & & \\
\hline 2. $A$ & 49,39 & 9,30 & $-0.20^{* *}$ & 1.00 & & & & & & & & & & & & & \\
\hline 3. $E$ & 2,47 & 0,63 & $0.14 *$ & $-0.18^{*}$ & 1.00 & & & & & & & & & & & & \\
\hline 4. $L P$ & 1,90 & 0,30 & 0.04 & -0.06 & 0.00 & 1.00 & & & & & & & & & & & \\
\hline 5. $\mathrm{CH}$ & 1,31 & 0,96 & 0.01 & -0.06 & -0.10 & $0.036^{* *}$ & 1.00 & & & & & & & & & & \\
\hline 6. ECJ & 17,70 & 10,14 & -0.05 & $0.61^{* *}$ & $-0.25^{* *}$ & -0.02 & 0.01 & 1.00 & & & & & & & & & \\
\hline 7. $A S$ & 3,51 & 0,95 & 0.02 & 0.01 & 0.07 & -0.01 & -0.03 & 0.14 * & 1.00 & & & & & & & & \\
\hline 8. HWW & 49,47 & 9,33 & -0.13 & -0.09 & -0.14 & -0.08 & -0.12 & 0.23 ** & 0.11 & 1.00 & & & & & & & \\
\hline 9. IO & 11,72 & 1,54 & -0.06 & -0.12 & 0.02 & 0.04 & 0.01 & $-0.15^{*}$ & 0.12 & 0.06 & $(0.72)$ & & & & & & \\
\hline 10. RTO & 11,83 & 1,42 & -0.06 & 0.01 & -0.04 & 0.07 & 0.04 & -0.04 & 0.06 & 0.10 & $0.41^{* *}$ & $(0.75)$ & & & & & \\
\hline 11. $P O$ & 11,03 & 1,67 & 0.05 & 0.01 & -0.08 & 0.01 & -0.02 & -0.02 & 0.05 & 0.07 & $0.54^{* *}$ & $0.32 * *$ & $(0.75)$ & & & & \\
\hline 12. $S G$ & 3,22 & 0,67 & 0.01 & -0.11 & 0.10 & 0.13 & 0.05 & -0.08 & 0.13 & $-0.15^{*}$ & $0.25 * *$ & $0.19 * *$ & $0.27^{* *}$ & 1.00 & & & \\
\hline 13. $S L$ & 3,91 & 0,64 & 0.02 & -0.06 & 0.14 & $0.17^{*}$ & 0.01 & -0.11 & 0.09 & $-0.16^{*}$ & $0.17^{*}$ & 0.01 & $0.29 * *$ & $0.41^{* *}$ & 1.00 & & \\
\hline 14. $S E A$ & 3,93 & 0,72 & -0.12 & -0.01 & 0.00 & 0.11 & 0.13 & -0.13 & 0.07 & -0.06 & $0.25^{* *}$ & 0.10 & $0.27^{* *}$ & $0.37^{* *}$ & $0.54^{* *}$ & 1.00 & \\
\hline 15. SO & 3,85 & 0,64 & 0.01 & -0.05 & 0.01 & 0.11 & -0.06 & -0.08 & 0.16 * & -0.11 & $0.39 * *$ & 0.11 & $0.25^{* *}$ & $0.46^{* *}$ & $0.43^{* *}$ & $0.51^{* *}$ & 1.00 \\
\hline
\end{tabular}

G: ender, A: age, E: education, LP: life-partner, CH: children, ECJ: experience in their current job, AS: activity sector, HWW: hours worked weekly, IO: innovative orientation, RTO: risk-taking orientation, PO: proactive orientation, SG: satisfaction with the growth, SL: satisfaction with life, SEA: satisfaction with the entrepreneurial activity, SO: satisfaction with the organization. Cronbach's alpha for the scales are shown along the diagonal. ${ }^{* *}$ Significant at $p<0.01,{ }^{*}$ significant at $p<0.05$. 
Table 2. Results of hierarchical linear regression models.

\begin{tabular}{|c|c|c|c|c|c|c|c|c|c|c|c|c|}
\hline & \multicolumn{3}{|c|}{$\begin{array}{c}\text { Model } 1 \\
\text { Satisfaction with the } \\
\text { Entrepreneurial Activity }\end{array}$} & \multicolumn{3}{|c|}{$\begin{array}{c}\text { Model 2 } \\
\text { Satisfaction with Life }\end{array}$} & \multicolumn{3}{|c|}{$\begin{array}{c}\text { Model } 3 \\
\text { Satisfaction with the } \\
\text { Organization }\end{array}$} & \multicolumn{3}{|c|}{$\begin{array}{l}\text { Model } 4 \\
\text { Satisfaction with the Growth }\end{array}$} \\
\hline & $\beta$ & $t$ & VIF & $\beta$ & $t$ & VIF & $\mathcal{\beta}$ & $t$ & VIF & $\beta$ & $t$ & VIF \\
\hline \multicolumn{13}{|l|}{ Step 1} \\
\hline G & -0.13 & -1.73 & 1.14 & -0.06 & -0.88 & 1.14 & -0.01 & -0.21 & 1.14 & -0.08 & -1.18 & 1.14 \\
\hline $\mathrm{Ag}$ & 0.10 & 1.08 & 1.96 & -0.04 & -0.38 & 1.96 & -0.04 & -0.47 & 1.96 & $-0.19 *$ & -1.99 & 1.96 \\
\hline $\mathrm{Ed}$ & 0.01 & 0.09 & 1.14 & 0.12 & 1.67 & 1.14 & -0.05 & -0.77 & 1.14 & 0.09 & 1.23 & 1.14 \\
\hline LP & 0.08 & 1.10 & 1.17 & $0.18^{* *}$ & 2.54 & 1.17 & 0.13 & 1.88 & 1.17 & 0.10 & 1.41 & 1.17 \\
\hline $\mathrm{Ch}$ & 0.11 & 1.44 & 1.19 & -0.05 & -0.69 & 1.19 & -0.14 & -1.90 & 1.19 & -0.01 & -0.12 & 1.19 \\
\hline ECJ & $-0.18 *$ & -1.85 & 2.04 & -0.03 & -0.34 & 2.04 & 0.01 & 0.07 & 2.04 & 0.11 & 1.16 & 2.04 \\
\hline AS & 0.09 & 1.22 & 1.07 & 0.09 & 1.31 & 1.07 & $0.13 *$ & 1.97 & 1.07 & 0.11 & 1.54 & 1.07 \\
\hline HWW & -0.03 & -0.41 & 1.27 & $-0.16 *$ & -2.11 & 1.27 & $-0.17 * *$ & -2.27 & 1.27 & $-0.23 * *$ & -2.99 & 1.27 \\
\hline \multicolumn{13}{|l|}{ Step 2} \\
\hline $\mathrm{IO}$ & 0.12 & 1.35 & 1.63 & 0.01 & 0.13 & 1.63 & 0.07 & 0.93 & 1.48 & 0.08 & 0.95 & 1.63 \\
\hline RTO & -0.05 & -0.60 & 1.25 & -0.10 & -1.34 & 1.25 & -0.06 & -0.81 & 1.25 & 0.10 & 1.30 & 1.25 \\
\hline $\mathrm{PO}$ & $0.22 * *$ & 2.69 & 1.48 & $0.33 * * *$ & 4.10 & 1.48 & $0.36 * * *$ & 4.25 & 1.63 & $0.22 * *$ & 2.65 & 1.48 \\
\hline $\mathrm{R}^{2}$ & 0.16 & & & 0.19 & & & 0.23 & & & 0.19 & & \\
\hline Adjusted $\mathrm{R}^{2}$ & 0.11 & & & 0.14 & & & 0.18 & & & 0.14 & & \\
\hline F Value & $5.80 * *$ & & & $7.56 * * *$ & & & $10.66^{* * *}$ & & & $7.26 * * *$ & & \\
\hline
\end{tabular}

G: ender, A: age, E: education, LP: life-partner, CH: children, ECJ: experience in their current job, AS: activity sector, HWW: hours worked weekly, IO: innovative orientation, RTO: risk-taking orientation, PO: proactive orientation, SG: satisfaction with the growth, SL: satisfaction with life, SEA: satisfaction with the entrepreneurial activity, SO: satisfaction with the organization, $\mathrm{t}$ : t-value; VIF: variance inflation factor, ${ }^{* * *}$ Significant at $p<0.001,{ }^{* *}$ significant at $p<0.01,{ }^{*}$ significant at $p<0.05$. Significant $p$ values $(p<0.05)$ were bolded for facilitating their identification. 
Hypothesises $\mathrm{H} 1, \mathrm{H} 2$ and $\mathrm{H} 3$ propose that innovative orientation, risk-taking orientation and proactive orientation positively influence entrepreneur's satisfaction with their entrepreneurial activity, life, organisation and the growth of the company. Nevertheless, the results show that independently of the control variables, proactive orientation is the only dimension of entrepreneurial orientation that had any explanatory power on the entrepreneur's satisfaction with the entrepreneurial activity, life, the organisation and the growth of the firm.

Our findings show that innovative orientation, risk-taking orientation and proactive orientation do not have the same influence on the entrepreneurial satisfaction explanation. These findings support those found in previous research, in which entrepreneurial orientation has been referred to as an individual level concept [13,17]. According to our results, hypotheses H1a, H1b, H1c, H1d, H2a, $\mathrm{H} 2 \mathrm{~b}, \mathrm{H} 2 \mathrm{c}$ and $\mathrm{H} 2 \mathrm{~d}$ were rejected. Specifically, our results show that innovative orientation and risk-taking orientation did not have a significant influence on the explanation of any of the dimensions of entrepreneur satisfaction used in the analysis. These results suggest that the previous findings, which showed significant relations between the dimensions of entrepreneurial orientation and the firm's objective success $[5,78,79]$, cannot be used to satisfactorily explain subjective success, entrepreneurial satisfaction. The most reasonable explanation for this fact could be found in that objective success, frequently measured using financial measures, and subjective success, although complementary, are two different concepts. Subjective success tries to find the degree to which the entrepreneur's expectations and his current situation match up. Objective success measures the current situation, or in any case the evolution of the observed variable (objective) between two moments in time [24]. Company sales may have undergone a strong growth in recent years, and be above the average growth values of companies in that sector. In spite of these values, entrepreneurial satisfaction with the growth may be low if he perceives that his expectations have not been met. On the other hand, the entrepreneur may perceive that this growth was achieved by working many more hours than he had planned and renouncing a large part of the time dedicated to family or leisure, which could lead him to show low satisfaction with his life.

The only dimension of entrepreneurial orientation that was significant in the explanation of entrepreneurial satisfaction was proactive orientation. Therefore, our results confirm hypotheses H3a, $\mathrm{H} 3 \mathrm{~b}, \mathrm{H} 3 \mathrm{c}$ and $\mathrm{H} 3 \mathrm{~d}$, which propose that an entrepreneur's proactive orientation positively influences satisfaction with their entrepreneurial activity, with life, with organisation and with the growth of their company. In the business context, proactive orientation refers to the entrepreneurial spirit of being a leader, and the intention to make use of the new opportunities arising in the market; to introduce new products and brands before the competition does; to eliminate products or activities that are "mature" or that are at the end of their life cycle [69]. The explanation of why proactive orientation is the dimension of entrepreneurial orientation that affects entrepreneurial satisfaction could be found in the characteristics of proactive individuals: (a) they enjoy being active and they do not stagnate in routines, rather they seek new challenges as an outlet for their energy; (b) they are aware of their capabilities and limitations (self-knowledge); (c) they plan and think for the medium and long-term, trying to anticipate future needs and problems; (d) they do not get carried away by emotions and they know how to manage stressful situations; (e) they are constant, disciplined, persuasive, sociable, flexible and they know how to learn from critiques [80]. These characteristics that define proactive people could explain the autoregulation of expectations and its contribution to the improvement of entrepreneurial satisfaction.

The results also show certain interesting effects of the control variables. Firstly, the hours of work per week showed a negative relation with satisfaction with life, the organisation and the growth of the firm. Long working hours to the venture limit the number of hours available for other (leisure) activities. High time investments in the business may also come at the expense of the family situation as it often leads to higher levels of work-family conflict [81]. Thus, our result could be related to an imbalance between the effort made and the expectations. The years directing the firm were negatively associated with the satisfaction with the entrepreneurial activity. These results are in line with those 
obtained by Carree and Verheul [21]. The explanation of this result could be both in the accumulation of the psychological load product of the passing of the years and in the change in relative importance given to the entrepreneurial activity with the passing of time.

Two other control variables that were related to entrepreneurial satisfaction were a life-partner and age. The first was positively associated with life satisfaction. This finding is probably related to the support that the entrepreneur has in his significant other and which helps to reduce his stress levels [21]. Age was negatively associated with satisfaction with growth. This result is in line with those who defend that as age increases entrepreneurs are less willing to take on risks and the higher dedication entailed by entering new markets or creating new products $[82,83]$. The variable sector was found to be significant in the explanation of organisational satisfaction. This result is in line with those obtained by Carree and Verheul [21] and Hosseini and Eskandari [78]. Education and gender had no explanatory power on any of the dependent variables considered in the study. Prior research has found contradictory results regarding the relation between these two variables and entrepreneurial satisfaction $[13,21,78]$.

\section{Robustness Analysis}

In models 1 to 4 , we used satisfaction with entrepreneurial activity, satisfaction with life, satisfaction with the organization and satisfaction with the growth of the firm as measures of entrepreneurial subjective success. In all these models, the independent variables were the three dimensions of entrepreneurial orientation. In all models, our results show a positive relation between proactive orientation and subjective success. Our findings show that the relation between the dimensions of entrepreneurial orientation and subjective success (entrepreneur's satisfaction) is stable and does not depend on how we measure the latter. These data support the robustness and credibility of our results.

\section{Conclusions, Further Developments and Implications}

To date, there are very few studies published that set out to study how the dimensions of entrepreneurial orientation affect the entrepreneur's subjective success, more specifically, his satisfaction. Our results show that socio-demographic variables influence each of the four dimensions of entrepreneur satisfaction considered in our study in a different way. Hours worked weekly is the socio-demographic variable that most contributes to the explanation of entrepreneur satisfaction, since it negatively influences their satisfaction with life, with organisation and with the growth of their company. On the other hand, our results indicate that the findings of the traditional research, which studied the relations between the dimensions of entrepreneurial orientation (independent variables) and corporate performance (dependent variable), do not fully apply when the dependent variable is the entrepreneur's satisfaction (subjective success). Moreover, the findings from this study provided empirical evidence that proves that within the framework of small enterprises, there is a positive association between entrepreneur's proactive orientation and their satisfaction. However, innovative orientation and risk-taking orientation did not help to explain any of the 4 dimensions of entrepreneur satisfaction considered in the present study.

This study sought to take one step further towards global understanding of the influence that entrepreneurial orientation has on entrepreneurial satisfaction. Two aspects of this study set it apart from most of those performed until now. Firstly, it used four dimensions of satisfaction to measure subjective success. Secondly, it used a time lagged design with two data-collection points. Entrepreneurial orientation was measured one year before measuring entrepreneurial satisfaction. Although the use of a time-lagged design did not permit to draw conclusions about cause-effect relationships among the study variables, it let us to test the hypothesized relationship in a more rigorous manner [84]. The amount of time that passed between measuring entrepreneurial orientation and satisfaction was explicitly included in the design of the analysis, in order to create a separation in time, context and psychology and to minimize the potential effects of common variance error. 
This study, as all studies, has several limitations that are worth noting. Firstly, we used a sample of entrepreneurs from a single country. It would be interesting to carry out similar research in other countries to determine whether our findings are replicated in different cultural environments [19]. Secondly, contextual factors such as politics, economics or tax or labour regulations or social factors, that could influence both entrepreneurial orientation and the entrepreneur's subjective success, were not taken into account in this research. Future research could take these factors into consideration. Thirdly, the reason the firm was created (by necessity, by choice or by opportunity), as well as the genesis of the firm that is being managed (new-creation firm, purchase of an existing firm, successor of a family firm) could affect entrepreneurial satisfaction. It would be interesting for future research to take into account these variables to further understand entrepreneurs' subjective success. Finally, our research was based on a sample of first owner-managers who run small firms. It would be interesting to check if our results are mirrored in samples of successors [53] and/or in larger companies.

Despite the limitations described, we believe that the results of this work have practical implications for entrepreneurs. Our results show that a key aspect of achieving greater subjective success is the entrepreneur's proactive orientation. Learning from failures, breaking routine, enjoying challenges, being aware of strengths and weaknesses, conducting medium and long-term planning, managing stressful situations and being more flexible could help entrepreneurs increase the degree of satisfaction with their business, with their life and with their organisation. Our results could also be useful for policymakers. The most satisfied entrepreneurs work more efficiently and maintain closer relations with different stakeholders, which would make them more likely to continue the business instead of closing. For this reason, and given the importance of entrepreneurs in creating wealth and maintaining employment [85], public policies aimed at promoting entrepreneurship should not forget to provide support for the development of programmes that aim to improve the entrepreneurial orientation of current and/or future entrepreneurs. This competence would fall mainly on those responsible for education, who should favour the introduction of teaching systems that train young people to develop their proactive orientation. In addition, our results are also interesting for business mentors and consultants who aim to help entrepreneurs anticipate changes that will occur in the markets, assess opportunities and threats in the environment and make decisions with which they feel satisfied. Some examples of how to achieve greater proactivity include: involving the entrepreneur in proactive problem solving, using personal initiative, making ideals, proactive feedback seeking and group dynamics that teach them to get out of their comfort zone [86].

Author Contributions: Conceptualization and methodology, G.M.-G. and J.-C.A.-C.; data collection and analysis, G.M.-G. and J.-C.A.-C.; writing, G.M.-G. and J.-C.A.-C.; review and commentary, G.M.-G. and J.-C.A.-C. All authors have read and agreed to the published version of the manuscript.

Funding: This research received no external funding.

Acknowledgments: The authors wish to thank all the participants that took part in this study.

Conflicts of Interest: The authors declare no conflict of interest.

\section{References}

1. Van Praag, C.M.; Versloot, P.H. What is the value of entrepreneurship? A review of recent research. Small Bus. Econ. 2007, 29, 351-382. [CrossRef]

2. Manzano-García, G.; Ayala Calvo, J.C. Psychometric properties of Connor-Davidson Resilience Scale in a Spanish sample of entrepreneurs. Psicothema 2013, 25, 245-251. [PubMed]

3. Vantilborgh, T.; Joly, J.; Pepermans, R. Explaining entrepreneurial status and success from personality: An individual-level application of the entrepreneurial orientation framework. Psychol. Belg. 2015, 55, 32-56. [CrossRef] [PubMed]

4. Khedhaouria, A.; Gurău, C.; Torrès, O. Creativity, self-efficacy, and small-firm performance: The mediating role of entrepreneurial orientation. Small Bus. Econ. 2014, 44, 485-504. [CrossRef] 
5. Krauss, S.I.; Frese, M.; Friedrich, C.; Unger, J.M. Entrepreneurial orientation: A psychological model of success among southern African small business owners. Eur. J. Work Organ. Psychol. 2005, 14, 315-344. [CrossRef]

6. Fernet, C.; Torrès, O.; Austin, S.; St-pierre, J. The psychological costs of owning and managing an SME: Linking job stressors, occupational loneliness, entrepreneurial orientation, and burnout. Burn. Res. 2016, 3, 45-53. [CrossRef]

7. Kollmann, T.; Christofor, J.; Kuckertz, A. Explaining individual entrepreneurial orientation: Conceptualization of a cross-cultural research framework. Int. J. Entrep. Small Bus. 2007, 4, 325-340. [CrossRef]

8. Ayala, J.C.; Manzano, G. The resilience of the entrepreneur. Influence on the success of the business. A longitudinal analysis. J. Econ. Psychol. 2014, 42, 126-135. [CrossRef]

9. Gorgievski, M.J.; Ascalon, M.E.; Stephan, U. Small business owners' success criteria, a values approach to personal differences. J. Small Bus. Manag. 2011, 49, 207-232. [CrossRef]

10. Shane, S.; Locke, E.A.; Collins, C.J. Entrepreneurial motivation. Hum. Resour. Manag. Rev. 2003, 13, $257-279$. [CrossRef]

11. Simpson, M.; Tuck, N.; Bellamy, S. Small business success factors: The role of education and training. Educ. + Train. 2004, 46, 481-491. [CrossRef]

12. Walker, E.; Brown, A. What success factors are important to small business owners? Int. Small Bus. J. 2004, 22, 577-594. [CrossRef]

13. Lian, J.W.; Yen, D.C. Understanding the relationships between online entrepreneurs' personal innovativeness, risk taking, and satisfaction: Comparison of pure-play and click-and-mortar. J. Organ. Comput. Electron. Commer. 2017, 27, 135-151. [CrossRef]

14. Cooper, A.C.; Artz, K.W. Determinants of satisfaction for entrepreneurs. J. Bus. Ventur. 1995, 10, $439-457$. [CrossRef]

15. Higgins, T. Self-discrepancy: A theory relating self and affect. Psychol. Rev. 1987, 94, 319-340. [CrossRef] [PubMed]

16. Lotz, H.M.; Van Der Merwe, S.P. An investigation of the influence of entrepreneurial orientation on the perceived success of agribusinesses in South Africa. S. Afr. J Bus Manag. 2013, 44, 15-32. [CrossRef]

17. Sriprasert, P. The effect of entrepreneurial orientation on the success of community enterprise: A study of Nakhon Si Thammarat, Thailand. Int. Proc. Econ. Dev. Res. 2013, 59, 158-162.

18. Casillas, J.C.; Moreno, A.M.; Barbero, J.L. A configurational approach of the relationship between entrepreneurial orientation and growth of family firms. Fam. Bus. Rev. 2010, 23, 27-44. [CrossRef]

19. Wickstrøm, K.; Liu, Y.; Schøtt, T. Entrepreneurs innovation bringing job satisfaction, work-family balance, and life satisfaction: In China and around the world. Int. J. Innov. Stud. 2017, 1, 193-206.

20. Dijkhuizen, J.; Gorgievski, M.; van Veldhoven, M.; Schalk, R. Feeling successful as an entrepreneur: A job demands-Resources approach. Int. Entrep. Manag. J. 2016, 12, 555-573. [CrossRef]

21. Carree, M.A.; Verheul, I. What makes entrepreneurs happy? Determinants of satisfaction among founders. J. Happiness Stud. 2012, 13, 371-387. [CrossRef]

22. Wach, D.; Stephan, U.; Gorgievski, M. More than money: Developing an integrative multi-factorial measure of entrepreneurial success. Int. Small Bus. J. 2016, 34, 1098-1121. [CrossRef]

23. Fisher, R.; Maritz, A.; Lobo, A. Evaluating entrepreneurs' perception of success. Int. J. Entrep. Behav. Res. 2014, 20, 478-492. [CrossRef]

24. Kliestik, T.; Misankova, M.; Valaskova, K.; Svabova, L. Bankruptcy prevention: New effort to reflect on legal and social changes. Sci. Eng. Ethics 2018, 24, 791-803. [CrossRef] [PubMed]

25. Ryan, R.M.; Deci, E.L. Self-determination theory and the facilitation of intrinsic motivation, social development, and well-being. Am. Psychol. 2000, 55, 68-78. [CrossRef] [PubMed]

26. Ferrante, F. Education, aspirations and life satisfaction. Kyklos 2009, 62, 542-562. [CrossRef]

27. Powell, G.N.; Eddleston, K.A. Linking family-to-business enrichment and support to entrepreneurial success: Do female and male entrepreneurs experience different outcomes? J. Bus. Ventur. 2013, 28, 261-280. [CrossRef]

28. Dej, D. Defining and measuring entrepreneurial success. In Entrepreneurship: A Psychological Approach; Lukes, M., Laguna, M., Eds.; Oeconomica Publishers: Prague, Czech Republic, 2010; pp. 89-102.

29. Fouquereau, E.; Rioux, L. Élaboration de l'échelle de satisfaction de vie professionnelle (ÉSVP) en langue française: Une démarche exploratoire. Can. J. Behav Sci. 2002, 34, 210-215. [CrossRef] 
30. Kraus, S.; Rigtering, J.P.C.; Hughes, M.; Hosman, V. Entrepreneurial orientation and the business performance of SMEs: A quantitative study from the Netherlands. Rev. Manag. Sci. 2012, 6, 161-182. [CrossRef]

31. Durana, P.; Valaskova, K.; Vagner, L.; Zadnanova, S.; Podhorska, I.; Siekelova, A. Disclosure of strategic managers' factotum: Behavioral incentives of innovative business. Int. J. Financ. Stud. 2020, 8, 17. [CrossRef]

32. Cromie, S. Assessing entrepreneurial inclinations: Some approaches and empirical evidence. Eur. J. Work Organ. Psychol. 2000, 9, 7-30. [CrossRef]

33. Schepers, J.; Voordeckers, W.; Steijvers, T.; Laveren, E. The entrepreneurial orientation-performance relationship in private family firms: The moderating role of socioemotional wealth. Small Bus. Econ. 2014, 43, 39-55. [CrossRef]

34. Shan, P.; Song, M.; Ju, X. Entrepreneurial orientation and performance: Is innovation speed a missing link? J. Bus. Res. 2016, 69, 683-690. [CrossRef]

35. Huhtala, H.; Diehl, M.-R. A review of employee well-being and innovativeness: An opportunity for a mutual benefit. Creat. Innov. Manag. 2007, 16, 299-306. [CrossRef]

36. Janssen, O.; Van Yperen, N.W. Employees' goal orientations, the quality of leader-member exchange, and the outcomes of job performance and job satisfaction. Acad. Manag. J. 2004, 47, 368-384.

37. Belias, D.; Koustelios, A. Organizational culture and job satisfaction. A review. Int. Rev. Manag. Mark. 2014, 4, 132-149.

38. Rasulzada, F.; Dackert, I. Organizational creativity and innovation in relation to psychological well-being and organizational factors. Creat. Res. J. 2009, 21, 191-198. [CrossRef]

39. West, M.; Anderson, N. Innovation in top management teams. J. Appl. Psychol. 1996, 81, 680-693. [CrossRef]

40. Delhey, J. From materialist to post-materialist happiness? National affluence and determinants of life satisfaction in cross-national perspective. Soc. Indic. Res. 2010, 97, 65-84. [CrossRef]

41. Blanchflower, D.; Oswald, A. International happiness: A new view on the measure of performance. Acad. Manag. Perspect. 2011, 25, 6-22.

42. Millán, J.; Hessels, S.; Thurik, R.; Aguado, R. Determinants of job satisfaction: A European comparison of self-employed and paid employees. Small Bus. Econ. 2013, 40, 651-670. [CrossRef]

43. Miller, D.H.; Friesen, P. Innovation in conservative and entrepreneurial firms: Two models of strategic momentum. Strateg. Manag. J. 1982, 3, 1-25. [CrossRef]

44. Knight, F.H. Risk, Uncertainty and Profit; University of Chicago Press: Chicago, IL, USA, 1971.

45. Tetrick, L.E.; Slack, K.J.; Da Silva, N.; Sinclair, R.R. A comparison of the stress-strain process for business owners and nonowners: Differences in job demands, emotional exhaustion, satisfaction, and social support. J. Occup. Health Psychol. 2000, 5, 464-476. [CrossRef] [PubMed]

46. Andersson, P. Happiness and Health: Well-Being among the Self-Employed. J. Socio Econ. 2008, 37, $213-236$. [CrossRef]

47. Javalgi, R.G.; Todd, P.R.; Johnston, W.J. Entrepreneurship, muddling through, and Indian Internet-enabled SMEs. J. Bus. Res. 2012, 65, 740-744. [CrossRef]

48. Pezderka, N.; Sinkovics, R. A conceptualization of e-risk perceptions and implications for small firm active online internationalization. Int. Bus. Rev. 2011, 20, 409-422. [CrossRef]

49. Andries, A.M.; Balutel, D.; Ihnatov, I.; Ursu, S.G. The nexus between corporate governance, risk taking, and growth. PLoS ONE 2020, 15, e0228371. [CrossRef]

50. Lorenz, M.P.; Gamble, J.E.; Turnipseed, D.L.; Weaver, K.M. Do owners and managers really differ?: An examination of satisfaction with overall firm performance in small and medium-sized enterprises. Int. J. Entrep. Innov. 2015, 16, 171-181. [CrossRef]

51. Acedo-Ramirez, M.A.; Ayala Calvo, J.C.A.; Navarrete-Martinez, E. Determinants of capital structure: Family businesses versus non-family firms. Czech J. Econ. Financ. 2017, 67, 80-103.

52. Romano, C.; Tanewski, G.; Smyrnios, K. Capital structure decision making: A Model for family business. J. Bus. Ventur. 2001, 16, 285-310. [CrossRef]

53. Lauto, G.; Pittino, D.; Visintin, F. Satisfaction of entrepreneurs: A comparison between founders and family business successors. J. Small Bus. Manag. 2019, 58, 474-510. [CrossRef]

54. Steijn, B. Determinants of organizational satisfaction in the Dutch Public Sector. In Proceedings of the NIG Annual Work Conference, Nijmegen, The Netherlands, 1 November 2005. 
55. Rauch, A.; Wiklund, J.; Lumpkin, G.T.; Frese, M. Entrepreneurial orientation and business performance: An assessment of past research and suggestions for the future. Entrep. Theory Pract. 2009, 33, 761-787. [CrossRef]

56. Siebert, J.; Kunz, R. Developing and validating the multidimensional proactive decision-making scale. Eur. J. Oper. Res. 2016, 249, 864-877. [CrossRef]

57. Siebert, J.; Kunz, R.E.; Rolf, P. Effects of proactive decision making on life satisfaction. Eur. J. Oper. Res. 2020, 280, 1171-1187. [CrossRef]

58. Erdogan, B.; Bauer, T. Enhancing career benefits of employee proactive personality: The role of fit with jobs and organizations. Pers. Psychol. 2005, 58, 859-891. [CrossRef]

59. Larrick, R.P. Broaden the decision frame to make effective decisions. In Handbook of Principles of Organizational Behavior: Indispensable Knowledge for Evidence-Based Management, 2nd ed.; Locke, E.A., Ed.; John Wiley \& Sons: Hoboken, NJ, USA; Chichester, Sussex, UK, 2011; pp. 461-480.

60. Judge, T.A.; Bono, J.E.; Locke, E.A. Core self-evaluations and job and life satisfaction: The role of self-concordance and goal attainment. J. Appl. Psychol. 2005, 90, 257-268. [CrossRef]

61. Njoki, P.; Mukulu, P.E.; Maurice, P. Relationship between managerial competence and growth of top 100 enterprises in Kenya. J. Hum. Resour. Leadersh. 2018, 2, 1-14.

62. Gosling, S.; Vazire, S.; Srivastava, S.; John, O.P. Should we trust web-based studies? A comparative analysis of six preconceptions about internet questionnaires. Am. Psychol. 2004, 59, 93-104. [CrossRef] [PubMed]

63. Jones, S.R.; Fernyhough, C.; de-Wit, L.; Meins, E. A message in the medium? Assessing the reliability of psychopathology e-questionnaires. Pers. Individ. Differ. 2008, 44, 349-359. [CrossRef]

64. Faul, F.; Erdfelder, E.; Buchner, A.; Lang, A.-G. Statistical power analyses using G*Power 3.1: Tests for correlation and regression analyses. Behav Res. Methods 2009, 41, 1149-1160. [CrossRef]

65. Hair, J.; Hult, T.; Ringle, C.; Sarstedt, M. A Primer on Partial Least Squares Structural Equation Modeling (PLS-SEM), 2nd ed.; Sage Publications, Inc.: London, UK, 2016.

66. IEF. La Empresa Familiar en España (2015); Instituto de la Empresa Familiar: Barcelona, Spain, 2015.

67. McCrae, R.; Costa, P.; Ostendorf, F.; Angleitner, A.; Hrebícková, M.; Avia, M.; Sanz, J.; Sánchez-Bernardos, M.L.; Kusdil, M.E.; Woodfield, R.; et al. Nature over nurture: Temperament, personality, and life span development. J. Pers. Soc. Psychol. 2000, 78, 173-186. [CrossRef] [PubMed]

68. Lumpkin, G.T.; Dess, G.G. Linking two dimensions of entrepreneurial orientation to firm performance: The moderating role of environment and industry life cycle. J. Bus. Ventur. 2001, 16, 429-451. [CrossRef]

69. Lechner, C.; Gudmundsson, S.V. Entrepreneurial orientation, firm strategy and small firm performance. Int. Small Bus. J. 2014, 32, 36-60. [CrossRef]

70. Martens, C.D.P.; Machado, F.J.; Martens, M.L.; Quevedo-Silva, F.; de Freitas, H.M.R. Linking entrepreneurial orientation to project success. Int. J. Proj. Manag. 2018, 36, 255-266. [CrossRef]

71. National Institute of Satistics. National Institute of Satistics [Internet]. 2018. Available online: http://www.ine.es/ss/Satellite?L=es_ES\&c=INEPublicacion_C\&cid=1259924856416\&p=1254735110672\& pagename=ProductosYServicios\%2FPYSLayout\&param1=PYSDetalleGratuitas (accessed on 3 March 2017).

72. Boes, S.; Staub, K.; Winkelmann, R. Relative status and satisfaction. Econ. Lett. 2010, 109, 168-170. [CrossRef]

73. Kibler, E.; Wincent, J.; Kautonen, T.; Cacciotti, G.; Obschonka, M. Can prosocial motivation harm entrepreneurs' subjective well-being? J. Bus. Ventur. 2018, 34, 608-624. [CrossRef]

74. Bergkvist, L.I.; Rossiter, J. The predictive validity of multiple-item versus single-item measures of the same constructs. J. Mark. Res. 2007, 44, 175-184. [CrossRef]

75. Garson, G.D. Statnotes: Topics in Multivariate Analysis [Internet]. 2009. Available online: http://faculty. chass.ncsu.edu/garson/pa765/statnote.htm (accessed on 5 December 2017).

76. GEM. Global Entrepreneurship Monitor. Informe GEM España 2018-2019. Global Entrepreneurship Monitor. Informe GEM España 2018-2019; Editorial de la Universidad de Cantabria, de la Asociación RED GEM España y de CIS E: Santander, Spain, 2019.

77. Hair, J.; Black, W.; Babin, B.; Anderson, R. Multivariate Data Analysis: A Global Perspective; Pearson New International Edition: Upper Saddle River, NJ, USA, 2014.

78. Hosseini, M.; Eskandari, F. Investigating entrepreneurial orientation and firm performance in the iranian agricultural context. J. Agric. Sci. Technol. 2013, 15, 203-214. 
79. Matchaba-Hove, T.; Farrington, S. The influence of entrepreneurial orientation on small business success. In The 23rd Annual Conference of the Southern African Institute for Management Scientists; Southern African Institute for Management Scientists: Durban, Kwazulu-Natal, South Africa, 2011.

80. Seibert, S.; Kraimer, M.; Crant, J.M. What do proactive pleople do? A longitudinal model linking proactive personality and career success. Pers. Psychol. 2001, 54, 845-874. [CrossRef]

81. Valcour, M. Work-based resources as moderators of the relationship between work hours and satisfaction with work-family balance. J. Appl. Psychol. 2007, 92, 1512-1523. [CrossRef]

82. Josef, A.; Richter, D.; Samanez-Larkin, G.; Wagner, G.; Hertwig, R.; Mata, R. Stability and change in risk-taking propensity across the adult life span. J. Pers. Soc. Psychol. 2016, 111, 430-450. [CrossRef] [PubMed]

83. Rolison, J.; Hanoch, Y.; Wood, S.; Liu, P.-J. Risk-taking differences across the adult life span: A question of age and domain. J. Gerontol. B Psychol. Sci. Soc. Sci. 2014, 69, 870-880. [CrossRef] [PubMed]

84. Valls, V.; González-Romá, V.; Tomás, I. Linking educational diversity and team performance: Team communication quality and innovation team climate matter. J. Occup. Organ. Psychol. 2016, 89, 751-771. [CrossRef]

85. Ratinho, T.; Amezcua, A.; Honig, B.; Zeng, Z. Supporting entrepreneurs: A systematic review of literature and an agenda for research. Technol Forecast. Soc. Chang. 2020, 154, 119956. [CrossRef]

86. Bindl, U.K.; Parker, S.K. Proactive work behavior: Forward-thinking and change-oriented action in organizations. In APA Handbook of Industrial and Organizational Psychology, Vol 2 Selecting and Developing Members for the Organization; Zedeck, S., Ed.; American Psychological Association: Washington, DC, USA, 2011; pp. 567-598.

(C) 2020 by the authors. Licensee MDPI, Basel, Switzerland. This article is an open access article distributed under the terms and conditions of the Creative Commons Attribution (CC BY) license (http://creativecommons.org/licenses/by/4.0/). 